\title{
Peroxo Complexes of Vanadium(V) Containing Aroylhydrazone Ligands
}

\author{
SIMPY MAHAJAN, BALGAR SINGH, H N SHEIKH* ${ }^{*}$ and BANSI LAL KALSOTRA
}

Department of Chemistry, University of Jammu, Jammu-180006, India

hnsheikh@rediffmail.com

Received 6 May 2012 / Accepted 15 May 2012

\begin{abstract}
The vanadium(V) peroxo complexes containing aroylhydrazone ligands having composition $\mathrm{Na}\left[\mathrm{VO}\left(\mathrm{O}_{2}\right)_{2} \mathrm{~L}-\mathrm{L}\right] \cdot 2 \mathrm{H}_{2} \mathrm{O}$ (where L-L = BFMH, BTEH, BTMH, BPMH, BAMH and $\mathrm{BCMH}$ ) are reported. The complexes were synthesized by stirring vanadium pentoxide with excess of $30 \%$ aqueous $-\mathrm{H}_{2} \mathrm{O}_{2}$ followed by treatment with methanolic solution of the ligand and finally maintained the $\mathrm{pH}$ of the reaction mixture by adding dilute solution of sodium hydroxide. The complexes have been characterized by various physicochemical techniques, viz. elemental analysis, molar conductivity, magnetic susceptibility measurements, infra red, electronic, mass, ${ }^{1} \mathrm{H}$ NMR spectral and TGA/DTA studies. These studies revealed that the complexes are uni-univalent electrolytes and diamagnetic in nature. The ligands are bound to metal in a bidentate mode through carbonyl oxygen or thiocarbonyl sulphur and nitrogen of amine group. Thermal analysis results provide conclusive evidence for the presence of two molecules of lattice water in the complexes. Mass spectra confirm the molecular mass of the complexes. Antifungal activity of complexes revealed enhanced activity of complexes as compared to corresponding free ligands. Molecular modeling has been used to suggest the energy minimized structures for the complexes.
\end{abstract}

Keywords: Peroxo complexes, aroylhydrazone ligands, Isotopic abundance, Antifungal activity, Lattice water, molecular modeling.

\section{Introduction}

For a variety of reasons, peroxo complexes have been the object of intense investigation for the past several years, including their role as oxidation catalyst ${ }^{1,2}$ and biochemical relevance $\mathrm{e}^{3-10}$. They are widely used in stoichiometric as well as catalytic oxidation in organic and biochemistry ${ }^{11}$, for example, in the oxidation of thioanisole ${ }^{12,13}$, methylbenzenes ${ }^{14}$, tertiary amines, alkenes, alcohols ${ }^{15,16}$, bromide ${ }^{17}$ and also in olefin epoxidations ${ }^{18-22}$. There has been a continuous upsurge in interest in peroxo compounds of vanadium since it has been demonstrated that vanadate and peroxovanadates are capable of inhibiting the hydrolysis of phosphoproteins ${ }^{23-26}$ and exhibit insulin-like properties ${ }^{27-31}$. Metal complexes of aroylhydrazones have broad applications in biological processes such as in the treatment of tumour, tuberculosis, leprosy and mental disorders ${ }^{32-35}$. These are also known to act as herbicides, insecticides and acaricides ${ }^{36,37}$. The biological activity has been attributed ${ }^{38}$ to the complex forming abilities of ligand with metal ions present in the cells. The present interest in the coordination chemistry of aroylhydrazones stems from their ligational behaviour ${ }^{39}$. 
These ligands can act both as neutral and mononegative ligands and favour certain geometries $^{40}$ to the complexes. Copper is widely used in various industrial operations. Therefore, the study of the corrosion inhibition of copper is a subject of pronounced practical significance. 2,4-Dinitrophenyl hydrazine and benzoyl benzaldehyde hydrazone derivatives have been used as effective corrosion inhibitors for copper ${ }^{41,42}$.

In the present work, we describe the synthesis and characterization of peroxo complexes of vanadium(V) with some aroylhydrazone ligands. The structures of ligands are given in Scheme 1.<smiles>O=C(N/N=C/c1ccco1)c1ccccc1</smiles>

Benzoic acid[1-(Furan-2-yl)methylene] hydrazide (BFMH)<smiles>O=C(N/N=C/c1ccccc1)c1ccccc1</smiles>

Benzoic acid (phenylmethylene) hydrazide(BPMH)<smiles>C/C(=N\NC(=O)c1ccccc1)c1cccs1</smiles>

Benzoic acid [1-(thiophene-2yl)ethylidene] hydrazide (BTEH)<smiles>COc1cccc(/C=N/NC(=O)c2ccccc2)c1</smiles>

Benzoic acid [(thiophene-2-yl)methylene] hydrazide (BTMH)<smiles>COc1cccc(/C=N/NC(=O)c2ccccc2)c1</smiles>

Benzoic acid[1-(anisol-3-yl)methylene] hydrazide (BAMH)<smiles>O=C(N/N=C/c1ccc(Cl)cc1)c1ccccc1</smiles>

Benzoic acid [(p-chlorobenzyl)methylene] hydrazide (BCMH)

\section{Scheme 1}

\section{Experimental}

Dimethyl sulphoxide (Ranbaxy), dimethyl formamide (Qualigen), ethanol, methanol (commercial) were used after distillation, furfuraldehyde (Himedia), thiophen-2carboxaldehyde (Himedia), 2-acetylthiophene (Himedia), anisaldehyde (Himedia), benzhydrazide (Fluka), p-chloro benzaldehyde (Merck), vanadium pentoxide (Thomas Baker) and hydrogen peroxide (Merck) were used as supplied. The ligands were prepared by the reported method ${ }^{43,44}$. 


\section{Physical measurements and analytical methods}

The analysis of vanadium was carried out gravimetrically as silver vanadate after decomposing the complex with concentrated nitric acid ${ }^{45}$. Carbon, hydrogen, nitrogen and sulphur were analyzed micro analytically using CHNS analyzer Leco Model-932. The total peroxide content of the complexes was determined by adding a weighed amount of the compound to a cold solution of $1.5 \%$ boric acid (w/v) in $0.7 \mathrm{M}$ sulfuric acid $(100 \mathrm{ml})$ and then titrating with standard cerium(IV) solution ${ }^{46}$. Molar conductivity of complexes was measured at room temperature by a Digital Conductivity Meter of model 611E having a conductivity cell with a cell constant of $1.0 \pm 10 \%$ using $10^{-3} \mathrm{M}$ solution of complexes in DMSO and water. Magnetic measurements were carried out by Gouy's method at room temperature using $\mathrm{Hg}\left[\mathrm{Co}(\mathrm{SCN})_{4}\right]$ as standard. IR spectra of complexes over the region 4000-400 $\mathrm{cm}^{-1}$ were recorded on Perkin Elmer's FTIR spectrophotometer model $\mathrm{RX} 1$, using $\mathrm{KBr}$ discs. Melting points were determined on Analab melting point apparatus and ${ }^{1} \mathrm{H}$ NMR spectra were obtained on a Bruker DPX $200 \mathrm{NMR}$ spectrometer (200 MHz) in DMSO- $\mathrm{d}_{6}$ using tetramethyl silane as an internal standard. Mass spectral data were obtained on ESI-esquires 3000 Bruker Daltonics spectrometer. Electronic spectra over the region 200-900 $\mathrm{nm}$ were recorded by UV-visible single beam spectrophotometer systronics using $10^{-3} \mathrm{M}$ DMSO solution of complexes. TGA/DTA studies were recorded on Linseis STA PT-1000 (Pyris Diamond) thermo-analyzer at the heating rate of $10{ }^{\circ} \mathrm{C}$ per minute in an atmosphere of nitrogen in the temperature range $25-1000{ }^{\circ} \mathrm{C}$. Antifungal activities were also carried out against the pathogen "Sclerotium rolfsii" by the poisoned food technique method. Molecular modeling studies have been carried out using Hyperchem release 8.0 to suggest the energy minimized structures for the complexes.

\section{Preparation of diperoxovanadate complexes}

In a typical reaction solid $\mathrm{V}_{2} \mathrm{O}_{5}(0.25 \mathrm{~g}, 1.37 \mathrm{~m}$ mol $)$ was stirred with methanolic solution of aroylhydrazones $(2.74 \mathrm{~m} \mathrm{~mol})$ : BFMH $(0.587 \mathrm{~g})$, BTEH $(0.669 \mathrm{~g})$, BTMH (0.631 g), BPMH (0.614 g), BAMH (0.697 g) and BCMH (0.709 g). To these mixture $12 \mathrm{ml}$ of $30 \% \mathrm{H}_{2} \mathrm{O}_{2}$ (105.84 m mol) was added gradually with constant stirring. Keeping the temperature below $4{ }^{\circ} \mathrm{C}$ in an ice bath, the mixture was stirred for 15 minutes until all solids dissolved. At this stage the $\mathrm{pH}$ was ca.6. The $\mathrm{pH}$ of the solution was then raised to 10 by drop wise addition of dilute sodium hydroxide solution $(0.1 \mathrm{M})$ with constant stirring. On adding pre-cooled ethanol (about $50 \mathrm{~mL}$ ) to this mixture under vigorous stirring a yellow coloured pasty mass separated out. After allowing to stand for about 15 minutes in an ice bath, light coloured precipitates were formed, which were then filtered and washed repeatedly with acetone and then dried in vacuo over calcium chloride at room temperature ${ }^{47}$.

$$
\begin{gathered}
\mathrm{V}_{2} \mathrm{O}_{5}+4 \mathrm{H}_{2} \mathrm{O}_{2}+2 \mathrm{~L}-\mathrm{L}+2 \mathrm{NaOH} \longrightarrow 2 \mathrm{Na}\left[\mathrm{VO}\left(\mathrm{O}_{2}\right)_{2} \mathrm{~L}-\mathrm{L}\right] \cdot 2 \mathrm{H}_{2} \mathrm{O}+\mathrm{H}_{2} \mathrm{O} \\
\text { where, } \mathrm{L}-\mathrm{L}=\mathrm{BFMH}, \mathrm{BTEH}, \mathrm{BTMH}, \mathrm{BPMH}, \mathrm{BAMH} \text { and BCMH. }
\end{gathered}
$$

\section{Results and Discussion}

The analytical and spectroscopic results (Tables 1-3) showed that all complexes are monomeric in nature with general formula, $\mathrm{Na}\left[\mathrm{VO}\left(\mathrm{O}_{2}\right)_{2} \mathrm{~L}-\mathrm{L}\right] \cdot 2 \mathrm{H}_{2} \mathrm{O}$ (where $\mathrm{L}-\mathrm{L}=$ $\mathrm{BFMH}, \mathrm{BTEH}, \mathrm{BTMH}, \mathrm{BPMH}, \mathrm{BAMH}$ and $\mathrm{BCMH}$ ). All the complexes are light coloured solids and are stable at room temperature. These are insoluble in water but fairly soluble in DMSO and DMF. The complexes do not have sharp melting points and decompose above $300{ }^{\circ} \mathrm{C}$. 
Table 1. Analytical data and some physical properties of vanadium(V) diperoxo complexes

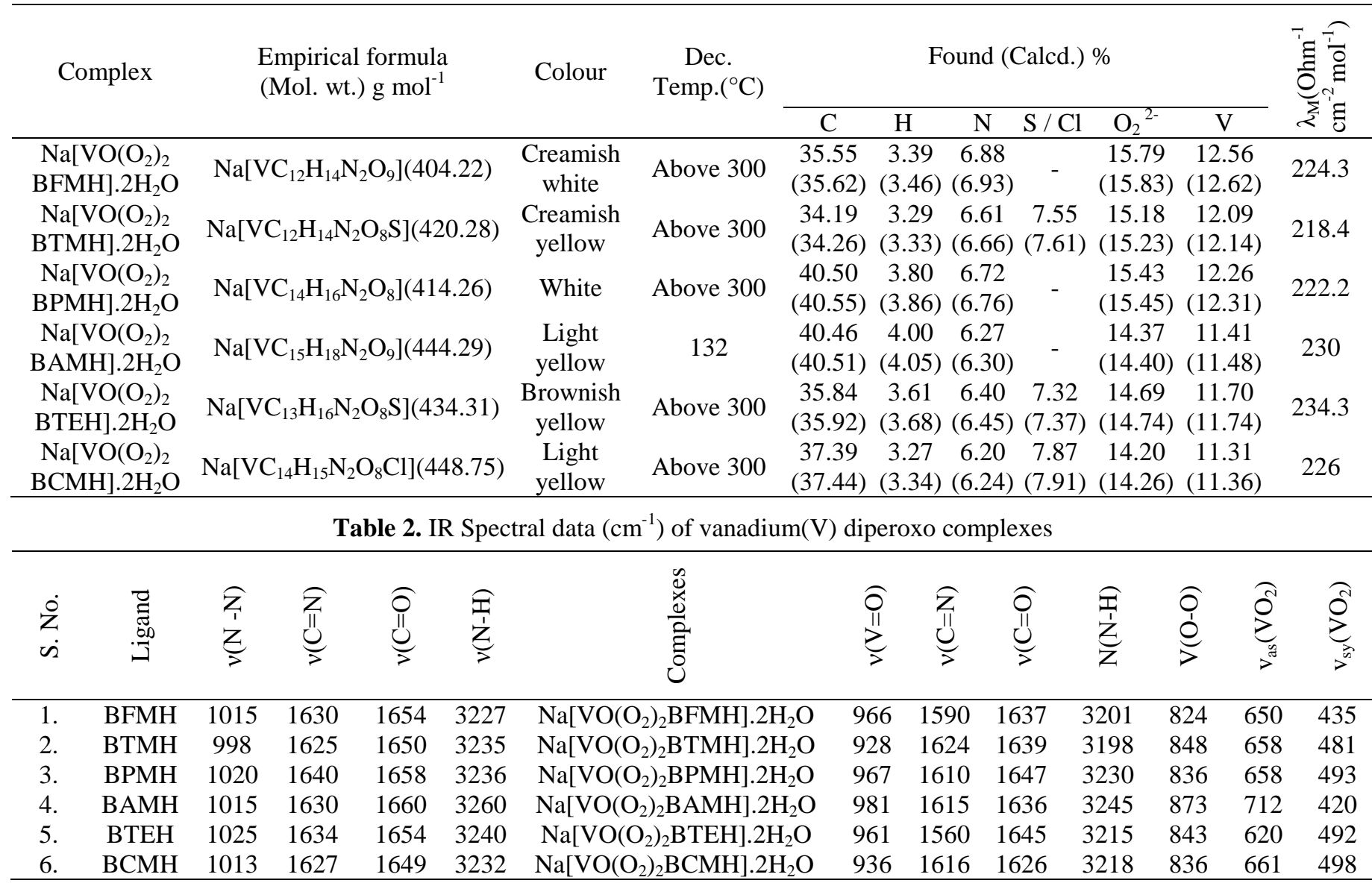


Table 3. Electronic Spectral data (nm) of vanadium(V) diperoxo complexes

\begin{tabular}{ccc}
\hline S.No. & Complex & $\lambda_{\text {max. }}(\mathrm{nm})$ \\
\hline 1. & $\mathrm{Na}\left[\mathrm{VO}\left(\mathrm{O}_{2}\right)_{2} \mathrm{BFMH}\right] .2 \mathrm{H}_{2} \mathrm{O}$ & 245 \\
2. & $\mathrm{Na}\left[\mathrm{VO}\left(\mathrm{O}_{2}\right)_{2} \mathrm{BTMH}\right] .2 \mathrm{H}_{2} \mathrm{O}$ & 256 \\
3. & $\mathrm{Na}\left[\mathrm{VO}\left(\mathrm{O}_{2}\right)_{2} \mathrm{BPMH}\right] .2 \mathrm{H}_{2} \mathrm{O}$ & 248 \\
4. & $\mathrm{Na}\left[\mathrm{VO}\left(\mathrm{O}_{2}\right)_{2} \mathrm{BAMH}\right] .2 \mathrm{H}_{2} \mathrm{O}$ & 241 \\
5. & $\mathrm{Na}\left[\mathrm{VO}\left(\mathrm{O}_{2}\right)_{2} \mathrm{BTEH}\right] .2 \mathrm{H}_{2} \mathrm{O}$ & 267 \\
6. & $\mathrm{Na}\left[\mathrm{VO}\left(\mathrm{O}_{2}\right)_{2} \mathrm{BCMH}\right] .2 \mathrm{H}_{2} \mathrm{O}$ & 261 \\
\hline
\end{tabular}

\section{Conductance and Magnetic measurements}

The molar conductivity values, $\lambda_{\mathrm{M}}$ of the complexes measured in DMSO solution lie in the range of 218.4-234.3 $\mathrm{Ohm}^{-1} \mathrm{~cm}^{2} \mathrm{~mol}^{-1}$ which indicates the uni-univalent electrolytic nature of these complexes ${ }^{48}$ (Table 1). Moreover, magnetic studies show that all the complexes are diamagnetic as expected for $\mathrm{d}^{0}$ system of diperoxovanadium(V) complexes.

\section{IR spectral studies}

The binding mode of aroyl hydrazone ligands with vanadium in the diperoxo complexes can be studied by comparing the IR spectra of the free ligands with those of corresponding metal complexes. The IR spectra of all the complexes (Table 2) exhibit bands characteristic of the coordinated oxo, peroxo groups and the ligand molecule. All the complexes show three vibrational bands around 824-873, 620-712, 420-498 $\mathrm{cm}^{-1}$, assigned to $v(\mathrm{O}-\mathrm{O})$ intra stretching, asymmetric $\mathrm{VO}_{2}$ stretching $\left(v_{\mathrm{as}}\right)$ and symmetric $\mathrm{VO}_{2}$ stretching $\left(v_{\mathrm{s}}\right)$ modes respectively. These bands confirm the $\eta^{2}$-coordination of the peroxo group ${ }^{49}$. An additional sharp band at 928-981 $\mathrm{cm}^{-1}$ has been assigned to $v(\mathrm{~V}=\mathrm{O})$ mode ${ }^{50-52}$. Thus, IR spectra confirms the presence of $\left[\mathrm{VO}\left(\mathrm{O}_{2}\right)_{2}\right]^{-}$moiety in these complexes.

The IR spectra for free ligands (Table 2) are consistent with existence of aroylhydrazones. All ligands exhibit a strong absorption band at ca. 3227-3260 $\mathrm{cm}^{-1}$ due to $v(\mathrm{~N}-\mathrm{H})$ stretching mode. Two strong bands at 1649-1660 and 1625-1640 $\mathrm{cm}^{-1}$ are attributed to amide $v(\mathrm{C}=\mathrm{O})$ and $v(\mathrm{C}=\mathrm{N})$ modes respectively, indicating that ligands exist in keto form ${ }^{53}$. All complexes exhibit a strong absorption band at ca. 3198-3245 $\mathrm{cm}^{-1}$ due to $v(\mathrm{~N}-\mathrm{H})$ stretching mode suggesting that all the ligands remain protonated on chelation. The amide bands $v(\mathrm{C}=\mathrm{O})$ and $v(\mathrm{C}=\mathrm{N})$ are shifted to lower frequencies in the spectra of complexes (Table 2) suggesting the involvement of carbonyl oxygen and azomethine nitrogen in coordination with metal ${ }^{54}$. Thus, these observations suggest that the ligands behave as neutral bidentate chelating type coordinating metal through carbonyl oxygen and azomethine nitrogen.

\section{Electronic spectral studies}

The electronic spectra of metal complexes in $10^{-3} \mathrm{M}$ DMSO were recorded in the UV-visible region (Table 3) show two high energy absorption bands in the region 241-267 $\mathrm{nm}$. These bands may be assigned to vanadyl oxygen $\rightarrow$ vanadium charge transfer, i.e. LMCT, $\pi \mathrm{O}_{2}{ }^{2-}$ $\rightarrow \mathrm{V}$ bands ${ }^{55}$. There was no evidence of any d-d transition. This result is consistent with the presence of vanadium(V) system in the complexes.

\section{${ }^{1}$ H NMR studies}

The ${ }^{1} \mathrm{H}$ NMR spectrum of the representative ligand, Benzoic acid [1-(anisol-3-yl) methylene] hydrazide (BAMH) was recorded in DMSO. The spectrum shows low field signals at $8.0 \mathrm{ppm}$ for the imino proton confirming the existence of ligands in keto form. The 
$\mathrm{CH}=\mathrm{N}$ peak is observed at $7.95 \mathrm{ppm}$ and signal due to aromatic protons which occur as multiplets appears between $7.44-7.94 \mathrm{ppm}$. The resonance signal due to $\mathrm{CH}_{3}$ protons present in BAMH ligand occurs at $3.73 \mathrm{ppm}$. The spectrum of the corresponding complex shows low field signals for imino proton at $7.9 \mathrm{ppm}$ (nearly same $\delta$ value as that of corresponding free ligands). Moreover, $\mathrm{CH}=\mathrm{N}$ peak in the complex is shifted towards higher $\delta$ value $(8.4 \mathrm{ppm})$ due to deshielding because of bonding of azomethine nitrogen with vanadium.

\section{ESI mass spectral studies}

The ESI mass spectra has been recorded for the complex $\mathrm{Na}\left[\mathrm{VO}\left(\mathrm{O}_{2}\right)_{2} \mathrm{BAMH}\right] \cdot 2 \mathrm{H}_{2} \mathrm{O}$. The complex shows extensive fragmentation and only the most abundant fragment ion (with relative isotopic abundance ${ }^{56}$ ) is given in Table 4 . The complex displayed molecular ion peak at $\mathrm{m} / \mathrm{e} 443.29$ for fragment $\left\{\mathrm{Na}\left[\mathrm{VO}\left(\mathrm{O}_{2}\right)_{2} \mathrm{C}_{15} \mathrm{H}_{14} \mathrm{O}_{2} \mathrm{~N}_{2}\right] .2 \mathrm{H}_{2} \mathrm{O}\right\}^{+}$. The base peak appears at $\mathrm{m} / \mathrm{e} 254.29$ corresponding to fragment $\left[\mathrm{C}_{15} \mathrm{H}_{14} \mathrm{O}_{2} \mathrm{~N}_{2}\right]^{+}$. One more significant peak appears in the mass spectrum of the complex at $\mathrm{m} / \mathrm{e} 425.29$ corresponding to $\left\{\mathrm{Na}\left[\mathrm{VO}\left(\mathrm{O}_{2}\right)_{2} \mathrm{C}_{15} \mathrm{H}_{14} \mathrm{O}_{2} \mathrm{~N}_{2}\right] \cdot \mathrm{H}_{2} \mathrm{O}^{+}\right.$. The intensities of all the fragments in the complex have been represented relative to base peak at $\mathrm{m} / \mathrm{e} 254.29$ (Table 4). Masses of fragment ions listed in Table are calculated using vanadium atom mass equal to $50.94 \mathrm{amu}$.

Table 4. Mass spectral data of vanadium(V) diperoxo complexes

\begin{tabular}{cccccc}
\hline $\begin{array}{c}\left.\text { Complex(I)Na[VO(O } \mathrm{O}_{2}\right)_{2} \mathrm{C}_{1} \\
\left.\mathrm{H}_{14} \mathrm{O}_{2} \mathrm{~N}_{2}\right] \cdot 2 \mathrm{H}_{2} \mathrm{O}(444.29)\end{array}$ & $\mathrm{m} / \mathrm{e}(\%)$ & $\begin{array}{c}\mathrm{M}-1^{*} \\
(\%)\end{array}$ & $\begin{array}{c}\mathrm{M}^{*} \\
(\%)\end{array}$ & $\begin{array}{c}\mathrm{M}+1^{*} \\
(\%)\end{array}$ & $\begin{array}{c}\mathrm{M}+2^{*} \\
(\%)\end{array}$ \\
\hline$\left\{\mathrm{Na}\left[\mathrm{VO}\left(\mathrm{O}_{2}\right)_{2} \mathrm{C}_{15} \mathrm{H}_{14} \mathrm{O}_{2} \mathrm{~N}_{2}\right] .2 \mathrm{H}_{2} \mathrm{O}\right\}^{+}$ & $443.29(25.4)$ & 0.25 & 100 & 17.5 & 3.3 \\
$\left\{\mathrm{Na}\left[\mathrm{VO}\left(\mathrm{O}_{2}\right)_{2} \mathrm{C}_{15} \mathrm{H}_{14} \mathrm{O}_{2} \mathrm{~N}_{2}\right] \cdot \mathrm{H}_{2} \mathrm{O}\right\}^{+}$ & $425.29(28.5)$ & 0.25 & 100 & 17.4 & 3.0 \\
$\left\{\mathrm{Na}\left[\mathrm{VO}\left(\mathrm{O}_{2}\right)_{2} \mathrm{C}_{15} \mathrm{H}_{14} \mathrm{O}_{2} \mathrm{~N}_{2}\right]\right\}^{+}$ & $407.29(7.1)$ & 0.25 & 100 & 17.4 & 2.8 \\
$\left\{\mathrm{Na}\left[\mathrm{VO}\left(\mathrm{O}_{2}\right) \mathrm{C}_{15} \mathrm{H}_{14} \mathrm{O}_{2} \mathrm{~N}_{2}\right]\right\}^{+}$ & $375.29(11.4)$ & 0.25 & 100 & 17.3 & 2.4 \\
$\left\{\mathrm{Na}\left[\mathrm{VO}\left(\mathrm{C}_{15} \mathrm{H}_{14} \mathrm{O}_{2} \mathrm{~N}_{2}\right)\right]\right\}^{+}$ & $343.29(27.1)$ & 0.25 & 100 & 17.2 & 2.0 \\
$\left\{\mathrm{Na}\left[\mathrm{V}\left(\mathrm{C}_{15} \mathrm{H}_{14} \mathrm{O}_{2} \mathrm{~N}_{2}\right)\right]\right\}^{+}$ & $327.29(25.7)$ & 0.25 & 100 & 17.2 & 1.8 \\
$\left\{\mathrm{Na}\left[\mathrm{V}\left(\mathrm{C}_{8} \mathrm{H}_{7} \mathrm{ON} \mathrm{ON}_{2}\right)\right]\right\}^{+}$ & $220.29(5.7)$ & 0.25 & 100 & 9.5 & 0.6 \\
$\left\{\mathrm{Na}\left[\mathrm{V}\left(\mathrm{C}_{7} \mathrm{H}_{6} \mathrm{ON}\right)\right]\right\}^{+}$ & $193.29(8.6)$ & 0.25 & 100 & 8.0 & 0.5 \\
$\left\{\mathrm{Na}\left[\mathrm{V}\left(\mathrm{C}_{6} \mathrm{H}_{5}\right)\right]\right\}^{+}$ & $150.29(24.3)$ & 0.25 & 100 & 6.5 & 0.2 \\
$\left\{\mathrm{Na}\left[\mathrm{C}_{6} \mathrm{H}_{5}\right]\right\}^{+}$ & $99.29(7.1)$ & - & - & 6.5 & 0.2 \\
$\mathrm{BAMH}$ & $254.29(100)$ & - & 100 & 17.2 & 1.8 \\
\hline
\end{tabular}

Vanadium has two isotopes having atomic masses 50 and $51 \mathrm{amu}$. Their relative abundances are $0.25 \%$ and $99.75 \%$ respectively. Here, the most intense isotope peak is set to $100 \%$ and percentages of other isotope peaks are computed relative to it (Table 4). The molecular ion and fragments peaks containing vanadium appear in doublet at $\mathrm{M}^{+} *$ and $\mathrm{M}-\mathrm{I}^{*}$ and ratios of their relative intensities confirm the presence of $\mathrm{V}-50$ and $\mathrm{V}-51$ isotopes in the fragments. In addition $\mathrm{M}+1 *$ and $\mathrm{M}+2 *$ peaks also appear due to isotopic contribution of $\mathrm{C}, \mathrm{H}, \mathrm{N}, \mathrm{O}$ and $\mathrm{S}$ atoms.

\section{TGA/DTA studies}

TGA and DTA thermograms are recorded up to $1000{ }^{\circ} \mathrm{C}$ for a representative complex $\mathrm{Na}\left[\mathrm{VO}\left(\mathrm{O}_{2}\right)_{2} \mathrm{BAMH}\right] \cdot 2 \mathrm{H}_{2} \mathrm{O}$ in an atmosphere of nitrogen at a heating rate of $10^{\circ} \mathrm{C} / \mathrm{min}$. The TG curve (Figure 1) for the complex $\mathrm{Na}\left[\mathrm{VO}\left(\mathrm{O}_{2}\right)_{2} \mathrm{BAMH}\right] \cdot 2 \mathrm{H}_{2} \mathrm{O}$ shows initially a weight loss starting from $31-300{ }^{\circ} \mathrm{C}$ which corresponds to weight loss of $15.30 \%$. This weight loss approximates to the loss of two outer sphere water molecules and one peroxo group (theoretical weight loss $15.45 \%$ ). The DTA curve of the complex shows a sharp endothermic peak at $112{ }^{\circ} \mathrm{C}$ confirming the loss of water molecule. Further heating up to 
$369^{\circ} \mathrm{C}$ shows a gradual weight loss of $10.50 \%$ (theoretical weight loss $10.80 \%$ ) attributable to loss of one more peroxo group as molecular oxygen and an oxo group. The weight loss continues beyond this temperature and finally attains a constant mass corresponding to [VNCH] (observed 62.2\%, calcd. 63.2\%).

Institute Instrumentation Centre, IITR, Roorkee.

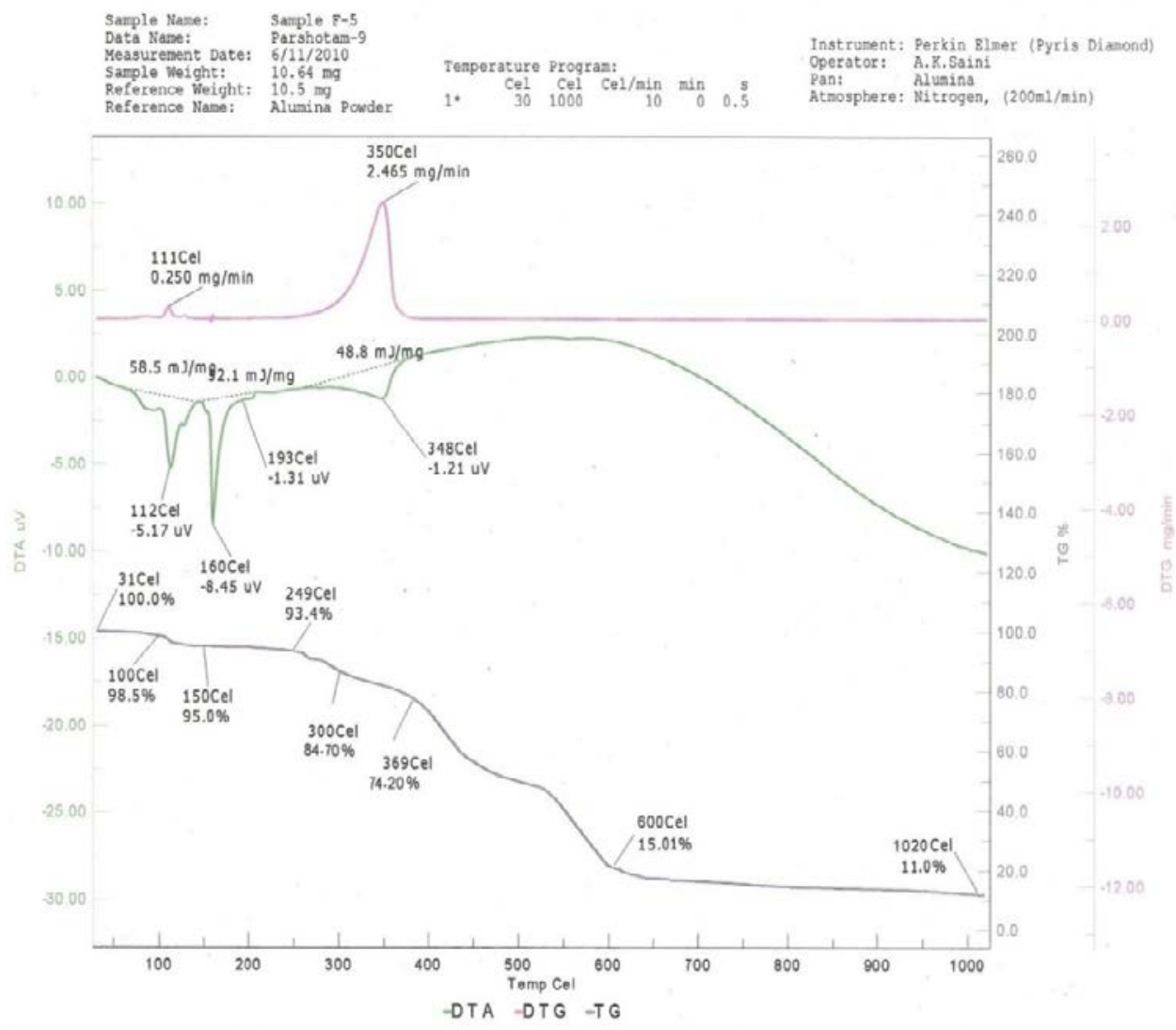

Figure 1. TGA/DTA thermogram of $\mathrm{Na}\left[\mathrm{VO}\left(\mathrm{O}_{2}\right)_{2} \mathrm{BAMH}\right] \cdot 2 \mathrm{H}_{2} \mathrm{O}$

\section{Molecular modeling}

Since single crystals could not be grown for these complexes, it was thought worthwhile to obtain structural information through molecular modeling. The molecular modeling calculations for the complexes, $\mathrm{Na}\left[\mathrm{VO}\left(\mathrm{O}_{2}\right)_{2} \mathrm{BAMH}\right] \cdot 2 \mathrm{H}_{2} \mathrm{O}$ (I) and $\mathrm{Na}\left[\mathrm{VO}\left(\mathrm{O}_{2}\right)_{2} \mathrm{BTMH}\right] .2 \mathrm{H}_{2} \mathrm{O}$ (II) has been carried out using Hyperchem release 8.0 professional version, which allows for rapid structural building, geometry optimization and molecular display ${ }^{57}$. Energy values obtained for the complex indicate pentagonal bipyramidal geometry. Figures 2(a \& b) and 2(c $\&$ d) show the energy-minimized structures for the complexes (I) and (II), respectively. The lowest energy values obtained from these studies for the complexes (I) and (II) are 358.35 and $372.16 \mathrm{k} \mathrm{cal} \mathrm{mol}^{-1}$ respectively. Selected bond lengths $(\AA)$ and bond angles $\left(^{\circ}\right)$ obtained from the energy-minimized structures are given in Table 5 . The probable structure thus exhibit molecular properties in conformity with experimentally determined data. 


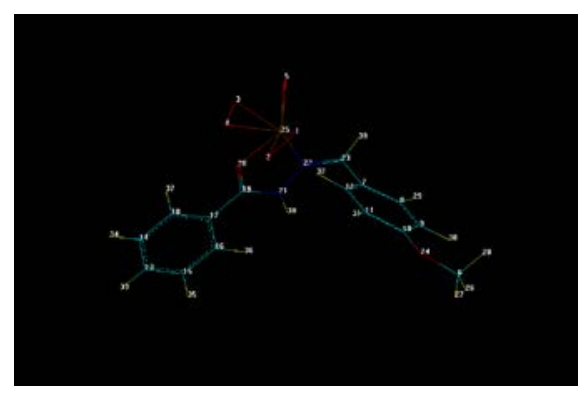

a

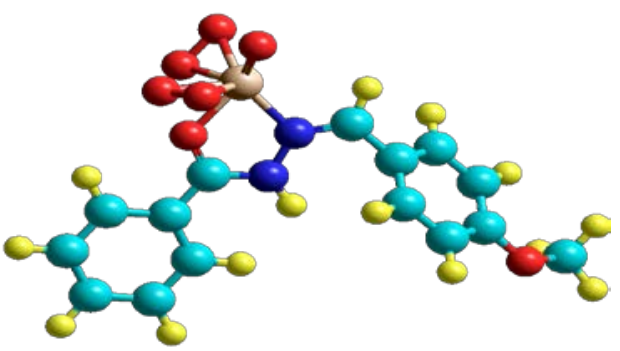

b

Figure 2. (a) Atomic Labeling; (b) Energy minimized structure of the complex $\mathrm{Na}\left[\mathrm{VO}\left(\mathrm{O}_{2}\right)_{2} \mathrm{BAMH}\right] \cdot 2 \mathrm{H}_{2} \mathrm{O}$ Colour codes for atoms: $\mathrm{H}=$ Yellow, $\mathrm{C}=$ Cyan, $\mathrm{N}=$ Blue, $\mathrm{O}=$ Red, $\mathrm{V}=$ Brown

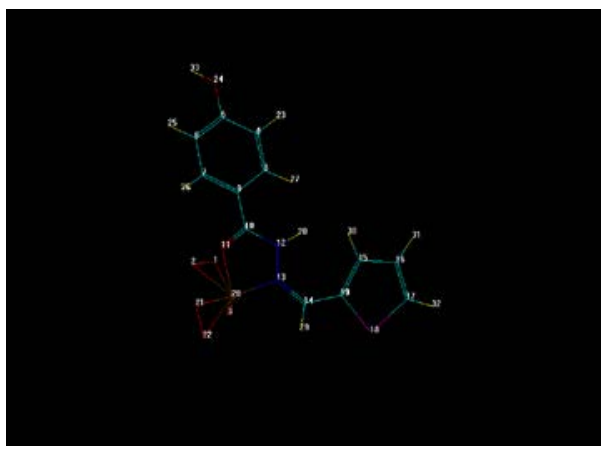

C

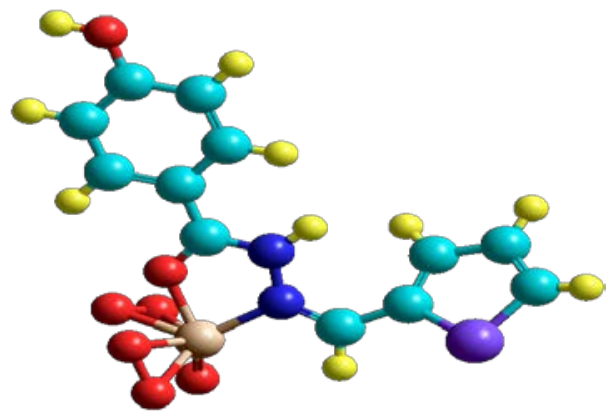

d

Figure 2. (c) Atomic Labeling; (d) Energy minimized structure of the complex $\mathrm{Na}\left[\mathrm{VO}\left(\mathrm{O}_{2}\right)_{2} \mathrm{BTMH}\right] \cdot 2 \mathrm{H}_{2} \mathrm{O}$ Colour codes for atoms: $\mathrm{H}=$ Yellow, $\mathrm{C}=\mathrm{Cyan}, \mathrm{N}=$ Blue, $\mathrm{O}=$ Red, $\mathrm{V}=$ Brown, $\mathrm{S}=$ Violet

Table 5. Selected bond lengths $\left(\mathrm{A}^{\circ}\right)$ and bond angles $\left({ }^{\circ}\right)$ for the complexes $\mathrm{Na}\left[\mathrm{VO}\left(\mathrm{O}_{2}\right)_{2}\right.$ BAMH]. $2 \mathrm{H}_{2} \mathrm{O} \& \mathrm{Na}\left[\mathrm{VO}\left(\mathrm{O}_{2}\right)_{2} \mathrm{BTMH}\right] \cdot 2 \mathrm{H}_{2} \mathrm{O}$

\begin{tabular}{|c|c|c|c|c|c|c|c|}
\hline \multicolumn{4}{|c|}{ Complex $\mathrm{Na}\left[\mathrm{VO}\left(\mathrm{O}_{2}\right)_{2} \mathrm{BAMH}\right] .2 \mathrm{H}_{2} \mathrm{O}$ (I) } & \multicolumn{4}{|c|}{ Complex $\mathrm{Na}\left[\mathrm{VO}\left(\mathrm{O}_{2}\right)_{2} \mathrm{BTMH}\right] .2 \mathrm{H}_{2} \mathrm{O}$ (II) } \\
\hline Bond & $\begin{array}{c}\text { Bond } \\
\text { Length } \\
(\AA)\end{array}$ & Angle & $\begin{array}{l}\text { Bond } \\
\text { angle } \\
\left({ }^{\circ}\right)\end{array}$ & Bond & $\begin{array}{c}\text { Bond } \\
\text { Length } \\
(\AA)\end{array}$ & Angle & $\begin{array}{c}\text { Bond } \\
\text { angle } \\
\left({ }^{\circ}\right)\end{array}$ \\
\hline $\begin{array}{c}\mathrm{V}(25)- \\
\mathrm{O}(4)\end{array}$ & 1.8888 & $\begin{array}{l}\mathrm{V}(25)-\mathrm{O} \\
(4)-\mathrm{O}(3)\end{array}$ & 69.86 & $\begin{array}{l}\mathrm{O}(2)- \\
\mathrm{V}(20)\end{array}$ & 1.8884 & $\begin{array}{c}\mathrm{V}(20)-\mathrm{O} \\
(22)-\mathrm{O}(21)\end{array}$ & 69.88 \\
\hline $\begin{array}{l}\mathrm{V}(25)- \\
\mathrm{O}(3)\end{array}$ & 1.8879 & $\begin{array}{c}\mathrm{O}(3)-\mathrm{V} \\
(25)-\mathrm{O}(4)\end{array}$ & 40.20 & $\begin{array}{l}\mathrm{O}(1)- \\
\mathrm{V}(20)\end{array}$ & 1.8876 & $\begin{array}{c}\mathrm{O}(21)-\mathrm{V} \\
(20)-\mathrm{O}(22)\end{array}$ & 40.27 \\
\hline $\begin{array}{l}\mathrm{V}(25)- \\
\mathrm{O}(5)\end{array}$ & 1.7799 & $\begin{array}{c}\mathrm{O}(4)-\mathrm{O} \\
(3)-\mathrm{V}(25)\end{array}$ & 69.93 & $\begin{array}{l}\mathrm{O}(22)- \\
\mathrm{V}(20)\end{array}$ & 1.8870 & $\begin{array}{c}\mathrm{O}(1)-\mathrm{V} \\
(20)-\mathrm{O}(2)\end{array}$ & 40.23 \\
\hline $\begin{array}{l}\mathrm{V}(25)- \\
\mathrm{O}(2)\end{array}$ & 1.8871 & $\begin{array}{l}\mathrm{V}(25)-\mathrm{O} \\
(2)-\mathrm{O}(1)\end{array}$ & 69.84 & $\begin{array}{l}\mathrm{O}(21) \\
\mathrm{V}(20)\end{array}$ & 1.8870 & $\begin{array}{l}\mathrm{V}(20)-\mathrm{O} \\
(2)-\mathrm{O}(1)\end{array}$ & 69.85 \\
\hline $\begin{array}{l}\mathrm{V}(25)- \\
\mathrm{O}(1)\end{array}$ & 1.8867 & $\begin{array}{l}\mathrm{V}(25)-\mathrm{O} \\
(1)-\mathrm{O}(2)\end{array}$ & 69.87 & $\begin{array}{l}\mathrm{O}(3)- \\
\mathrm{V}(20)\end{array}$ & 1.7799 & $\begin{array}{c}\mathrm{O}(2)-\mathrm{O} \\
(1)-\mathrm{V}(20)\end{array}$ & 69.92 \\
\hline
\end{tabular}




\begin{tabular}{|c|c|c|c|c|c|c|c|}
\hline $\mathrm{O}(3)-\mathrm{O}(4)$ & 1.2980 & $\begin{array}{c}\mathrm{O}(5)-\mathrm{V} \\
(25)-\mathrm{O}(1)\end{array}$ & 91.93 & $\begin{array}{l}\text { N(13)- } \\
\text { V(20) }\end{array}$ & 1.9045 & $\begin{array}{l}\mathrm{N}(13)-\mathrm{V} \\
(20)-\mathrm{O}(3)\end{array}$ & 122.46 \\
\hline $\mathrm{O}(2)-\mathrm{O}(1)$ & 1.2994 & $\begin{array}{c}\mathrm{O}(20)-\mathrm{V} \\
(25)-\mathrm{N}(22)\end{array}$ & 76.83 & $\begin{array}{l}\mathrm{O}(11)- \\
\mathrm{V}(20)\end{array}$ & 1.8566 & $\begin{array}{c}\mathrm{O}(11)-\mathrm{V} \\
(20)-\mathrm{N}(13)\end{array}$ & 76.79 \\
\hline $\begin{array}{l}\mathrm{V}(25)- \\
\mathrm{O}(20)\end{array}$ & 1.8568 & $\begin{array}{c}\mathrm{O}(5)-\mathrm{V} \\
(25)-\mathrm{O}(3)\end{array}$ & 61.20 & $\begin{array}{l}\mathrm{O}(21)- \\
\mathrm{O}(22)\end{array}$ & 1.2992 & $\begin{array}{l}\mathrm{O}(22)-\mathrm{V} \\
(20)-\mathrm{O}(3)\end{array}$ & 92.01 \\
\hline $\begin{array}{l}\mathrm{V}(25)- \\
\mathrm{N}(22)\end{array}$ & 1.9037 & $\begin{array}{c}\mathrm{O}(4)-\mathrm{V} \\
(25)-\mathrm{O}(2)\end{array}$ & 69.02 & $\mathrm{O}(1)-\mathrm{O}(2)$ & 1.2986 & $\begin{array}{c}\mathrm{O}(1)-\mathrm{V} \\
(20)-\mathrm{O}(11)\end{array}$ & 69.27 \\
\hline $\begin{array}{l}\mathrm{C}(9)- \\
\mathrm{O}(20)\end{array}$ & 1.2301 & $\begin{array}{c}\mathrm{N}(22)-\mathrm{V} \\
(25)-\mathrm{O}(5) \\
\mathrm{O}(5)-\mathrm{V}\end{array}$ & 122.47 & - & - & $\begin{array}{c}\mathrm{O}(3)-\mathrm{V} \\
(20)-\mathrm{O}(21) \\
\mathrm{O}(22)-\mathrm{V}\end{array}$ & 121.73 \\
\hline- & - & $(25)-\mathrm{O}(20)$ & 130.94 & - & - & $(20)-\mathrm{O}(1)$ & 120.44 \\
\hline- & - & $\begin{array}{l}\mathrm{O}(20)-\mathrm{V} \\
(25)-\mathrm{O}(3)\end{array}$ & 113.52 & - & - & $\begin{array}{c}\mathrm{O}(2)-\mathrm{V} \\
(20)-\mathrm{O}(21)\end{array}$ & 68.79 \\
\hline
\end{tabular}

\section{Antifungal activity}

$*=$ Relative isotopic abundances

The in vitro biological screening effects of the investigated compounds in DMSO (Table 6) were tested against the pathogen "Sclerotium rolfsii" by the poisoned food technique method using Potato Dextrose Agar (PDA) nutrient as the medium. The inoculated plates were incubated at $27^{\circ} \mathrm{C}$ for 5 days. The growth inhibition of "Sclerotium rolfsii" over control was calculated as per Vincent ${ }^{58}$.

Table 6. In vitro efficacy of complexes against Sclerotium rolfsii

\begin{tabular}{|c|c|c|c|c|c|c|c|c|c|}
\hline \multirow{2}{*}{$\begin{array}{l}\sum_{j}^{\dot{j}} \\
\dot{1} \\
1 .\end{array}$} & \multirow{2}{*}{$\left.\left(\mathrm{O}_{2}\right)_{2} \mathrm{BFMH}\right] .2 \mathrm{H}_{2} \mathrm{O}$} & \multicolumn{2}{|c|}{ 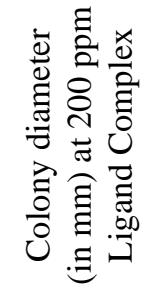 } & \multicolumn{2}{|c|}{ 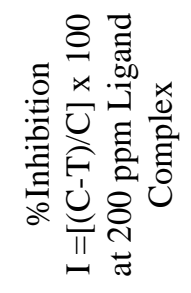 } & \multicolumn{2}{|c|}{ 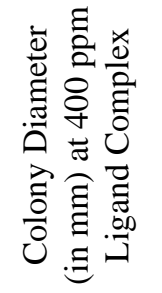 } & \multicolumn{2}{|c|}{ 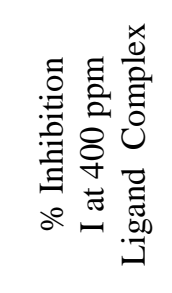 } \\
\hline & & 6.6 & 5.6 & 89.8 & 91 & .2 & 4. & O & 93. \\
\hline 2. & $\mathrm{Na}\left[\mathrm{VO}\left(\mathrm{O}_{2}\right)_{2} \mathrm{BTMH}\right] \cdot 2 \mathrm{H}_{2} \mathrm{O}$ & 6.9 & 5.7 & 89.4 & 91.2 & 6.6 & 4. & 89.8 & 93.4 \\
\hline 3 & $\mathrm{Na}\left[\mathrm{VO}\left(\mathrm{O}_{2}\right)_{2} \mathrm{BPMH}\right] \cdot 2 \mathrm{H}_{2} \mathrm{O}$ & 6.5 & 5.5 & 90 & 91.5 & 6.1 & 4.3 & 90.6 & 93.4 \\
\hline 4 & $\mathrm{Na}\left[\mathrm{VO}\left(\mathrm{O}_{2}\right)_{2} \mathrm{BAMH}\right] \cdot 2 \mathrm{H}_{2} \mathrm{O}$ & 6.4 & 5.2 & 90.2 & 92 & 6.2 & 4.6 & 90.5 & 92.9 \\
\hline 5 & $\mathrm{Na}\left[\mathrm{VO}\left(\mathrm{O}_{2}\right)_{2} \mathrm{BTEH}\right] .2 \mathrm{H}_{2} \mathrm{O}$ & 6.5 & 5.8 & 90 & 91.1 & 6.0 & 4.1 & 90.8 & 93.7 \\
\hline 6 & $\mathrm{Na}\left[\mathrm{VO}\left(\mathrm{O}_{2}\right)_{2} \mathrm{BCMH}\right] \cdot 2 \mathrm{H}_{2} \mathrm{O}$ & 6.7 & 5.8 & 89.7 & 91.1 & 6.5 & 4.0 & 90 & 93.8 \\
\hline
\end{tabular}

Colony diameter of control, $C=65 \mathrm{~mm}$

$\%$ Inhibition $(\mathrm{I})=[(\mathrm{C}-\mathrm{T}) / \mathrm{C}] \times 100$

Where $\mathrm{I}=$ Percent Inhibition, $\mathrm{C}=$ Growth of fungus in $(\mathrm{mm})$ in control, $\mathrm{T}=$ Growth of fungus in $(\mathrm{mm})$ in treatment. Zones developed on the plates are measured by measuring the diameter of the inhibited zone in millimeters. The zone of inhibition values are presented in the Table 6. It is evident that on increasing the concentration of the complexes, the colony diameter of the fungus decreases and hence percent inhibition increases as compared to corresponding ligands. Antifungal activity of $\mathrm{Na}\left[\mathrm{VO}\left(\mathrm{O}_{2}\right)_{2} \mathrm{BAMH}\right] \cdot 2 \mathrm{H}_{2} \mathrm{O}$ is shown in Figure 3. 


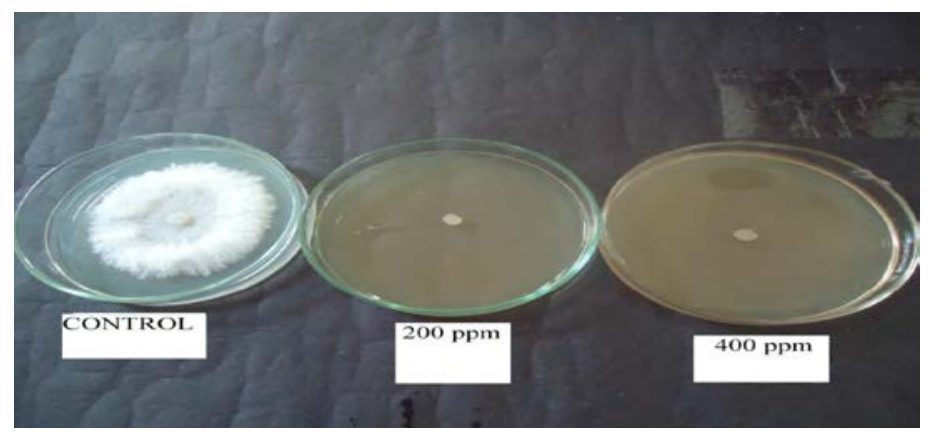

Figure 3. Antifungal activity of $\mathrm{Na}\left[\mathrm{VO}\left(\mathrm{O}_{2}\right)_{2} \mathrm{BAMH}\right] \cdot 2 \mathrm{H}_{2} \mathrm{O}$ against "Sclerotium rolfsii"

\section{Conclusion}

On the basis of analytical and physico-chemical data it is proposed that these complexes are mononuclear with composition $\mathrm{Na}\left[\mathrm{VO}\left(\mathrm{O}_{2}\right)_{2} \mathrm{~L}-\mathrm{L}\right] \cdot 2 \mathrm{H}_{2} \mathrm{O}$ (where L-L = BFMH, BTEH, $\mathrm{BTMH}, \mathrm{BPMH}, \mathrm{BAMH}$ and $\mathrm{BCMH}$ ). IR spectral studies of complexes suggest the involvement of carbonyl oxygen and azomethine nitrogen in coordination with metal. The electronic spectra of complexes do not show any absorption band responsible for d-d transitions suggesting an electronic configuration of $d^{0}(+5)$ for vanadium in these complexes. Magnetic studies reveal diamagnetic nature of complexes thus confirming the +5 oxidation state of vanadium. Molar conductance values of complexes indicate that these complexes behave as 1:1 electrolytes. Thermal studies depict the presence of two water molecules, two peroxo and one oxo group in all the complexes. ${ }^{1} \mathrm{H}$ NMR suggests the involvement of carbonyl oxygen and azomethine nitrogen in coordination with vanadium. Bond angles and bond lengths as obtained from molecular modeling studies reveal a distorted pentagonal bipyramidal structure for these complexes. Antifungal studies show that all the complexes are biologically more active than their corresponding ligands. On the basis of above facts, following structure is proposed for these complexes:

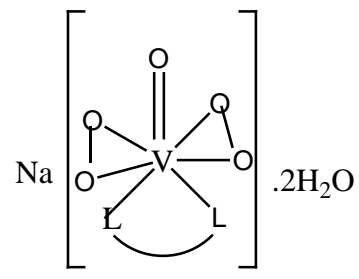

\section{References}

1. $\quad$ Butler A, Clague M J and Meister G E, Chem Rev., 1994, 94, 625-638.

2. Mimoun H, Mignard M, Brechot P and Saussine L, J Am Chem Soc., 1986, 108, 3711-3718.

3. Crans D C, Smee J J, Gaidamauskas E and Yang L, Chem Rev., 2004, 104(2), 849-902.

4. Thompson K H, McNeill J H and Orvig C, Chem Rev., 1999, 99, 2561-2572.

5. Thompson K H and Orvig C, J Chem Soc Dalton Trans., 2000, 2885-2892.

6. Haldar A K, Banerjee S, Naskar K, Kalita D, S Islam Nashreen and Roy Syamal, Experimental Parasitology, 2009, 122, 145-154.

7. Saleem Mohd, Sharma Mohita, Sheikh H N and Kalsotra B L, Indian J Chem., 2007, 46A, 1423-1426.

8. Sharma Mohita, Sheikh H N, Pathania M Singh and Kalsotra B L, J Coord Chem., 2008, 61(3), 426-434. 
9. Kalita D, Sarmah S, Das S P, Baishya D, Patowary A, Baruah S and S Islam Nashreen, Reactive and Functional Polymers, 2008, 68, 876-890.

10. Sharma Mohita, Saleem Mohd, Pathania M Singh, Sheikh H N and Kalsotra B L, Chinese Journal of Chemistry, 2009, 27, 311-316.

11. Tamani B and Yeganeh H, J Eur Polym., 1999, 35, 1445.

12. Chiarini M, Gillitt N D and Bunton C A, Langmuir, 2002, 18, 3836-3842.

13. Bunton C A and Gillitt N D, J Phys Org Chem., 2002, 15, 29-35.

14. Bandyopadhyay R, Biswas S, Guha S, Mukherjee A K and Bhattacharya R, Chem Commun., 1999, 1627.

15. Bortolini O S, Compestrini S F D, Furia F D and Modena G, J Org Chem, 1987, 52, 5467.

16. Bailey A J, Griffith W P and Parkin B C, J Chem Soc Dalton Trans., 1995, 1833-1837.

17. Reynolds M S, Morandi S J, Raebiger J W, Melican S P and Smith S P E, Inorg Chem., 1994, 33, 4977-4984.

18. Deubel D V, Sundermeyer J and Frenking G, Inorg Chem., 2000, 65, 2996.

19. Wahl G, Kleinhenz D, Schorm A, Sundermeyer J, Stowasser R, Rummey C, Bringmann G, Fickert C and Kiefer W, Chem Eur J., 1999, 5, 3237-3251.

20. Cross R J, Newman P D, Peacock R D and Stirling D, J of Mol Catalysis A: Chem., 1999, 144(2), 273-284.

21. Deubel D V, Sundermeyer J and Frenking G, J Am Chem Soc., 2000, 122, 1010110108.

22. Wang X Y, Shi H C and Xu S Y, J Mol Catal A: Chem., 2003, 206, 213-223.

23. Fantus I G, Kodata S, Deregon G, Foster B and Posner B, Biochem., 1989, 28, 88648891.

24. Crans D C, Smee J J, Gaidamauskas E and Yang L, Chem Rev., 2004, 104, 849-902.

25. Kustin K, In: Tracey A S, Crans D C, (Eds) Vanadium compounds chemistry, biochemistry, and therapeutic applications, Oxford Univ. Press, New York. 1998, 170.

26. Crans D C, In: Tracey A S, Crans D C, (eds) Vanadium compounds chemistry, biochemistry, and therapeutic applications, Oxford Univ. Press, New York. 1998, 82.

27. Thompson K H, Mc Neill J H and Orvig C, Chem Rev.,1999, 99, 2561.

28. Dubyak G R and Kleinzeller A D, J Biol Chem., 1980, 255, 5306-5312.

29. Rehder D, Bashirpoor M, Jantzen S, Schmidt H, Farahbakhsh M, Nekola H, In: Tracey A S and Crans D C (Eds), Vanadium compounds, chemistry, biochemistry and therapeutic applications, Oxford Univ. Press, New York, 1998, 60-70.

30. Shechter Y, Goldwaser I, Mironchik M, Fridkin M and Gefel D, Coord Chem Rev., 2003, 237, 3-11.

31. Djordjevic C, Vuletic N, Renslo M L, Puryear B C and Alimard R, Mol Cell Biochem., 1995, 153, 25-29.

32. Merubi M, Adediran D and Ugo B, Synth React Inorg Met-org Chem., 1993, 23, 435.

33. Mohan M, Kumar A, Kumar M and Jha N K, Inorg Chim Acta, 1987, 136, 65-74.

34. Saleem M, Sharma M, Sheikh H N and Kalsotra B L, Indian J Chem., 2007, 46A, 1423-1426.

35. Saleem M, Sharma M, Sheikh H N and Kalsotra B L, J Coord Chem., 2008, 61(14), 2334-2339.

36. Moon M W, Friedman A R and Stienhard A, J Agr Food Chem., 1972, 20, 1187 and Chem Abstr., 1986, 105, 7839.

37. Abdel-Aal M T, Abdel-Aleem H, Abdel-Aleem Laila, Ibahim I and Zein Ahmed L, Archives of Pharmacal Res., 2010, 33(12), 1891-1900.

38. Srivastava R S, Inorg Chim Acta, 1981, 56, L65. 
39. Rao M Sayaji and Reddy K Hussain, Indian J Chem., 1996, 35A, 681.

40. Dutta R L and Hussain Md M, J Sci Ind Res., 1985, 44, 635-674.

41. Fouda A S, Gouda M M and Abd El-Rahman S I, Chem Pharm Bull., 2000, 48(5), 636-640.

42. Maayta A K, Bitar M B and Al-Abdallah M M, Br Corros J., 2001, 36, 133-135.

43. Raman N, Vimalaramani R and Thangaraja C, Indian J Chem., 2004, 43A, 2357-2360.

44. $\quad$ Prabhu G Venkatesa and Venkappayya D, J Indian Chem Soc., 1995, 72, 511-514; 681-684.

45. Vogel A I, Quantitative Inorganic Analysis, $4^{\text {th }}$ ed., EBLS and Longman, London, 1968, 488.

46. Chaudhuri M K, Ghosh S K and Islam N S, Inorg Chem., 1985, 24, 2706-2707.

47. Hazarika P, Sarmah S, Kalita D and Islam N S, Trans Met Chem., 2008, 33, 69-77.

48. Paul G S, George R L and Lyle R D, J Phys Chem., 1956, 60(10), 1433-1436.

49. Djordjevic C, Vuletic N, Jacobs B A, Renslo M L and Sinn E, Inorg Chem., 1997, 36(9), 1798-1805.

50. Connor J A and Ebsworth E A V, Adv Inorg Chem Radiochem., 1964, 6, 292.

51. Lever A B P and Gray H B, Acc Chem Res., 1978, 11, 348-355.

52. Nakamoto Kazuo, IR and Raman Spectra of Inorg and Coord Compds.,1986, $4^{\text {th }}$ Ed., 262.

53. Rastogi D K and Sharma K C, J Inorg Nucl Chem., 1974, 36, 2219-2222.

54. Lal R A, Choudhury S, Ahmed A, Chakraborty M, Borthakur R and Kumar A, $J$ Coord Chem., 2009, 62(23), 3864-3874.

55. Heo Y S, Ryu J M, Park S M, Park J H, Lee H C, Hwang K Y and Kim J, Exp Mol Med., 2002, 34(3), 211-223.

56. Dass C, Fundamentals of Contemporary Mass Spectrometry, WISMS, Wiley Interscience, John Wiley and Sons, Inc, Hoboken, New Jersey, 2007, 203-208.

57. Dharmaraj N, Viswanathamurthi P and Natarajan K, Trans Met Chem., 2001, 26, 105-109.

58. Swalen J D and Ibers J A, J Chem Phys., 1962, 37, 17. 